\title{
Study on Risks and Supervision of P2P Network Lending Platform
}

\author{
Hong Chen \\ NO.99 Shangda Road, Baoshan District, Shanghai, China \\ chenhong_julia@163.com
}

Keywords: P2P network lending platform, Risk regulatory, Logic model

\begin{abstract}
In recent years, Internet finance has attracted the attention of the masses of people. As a new type of "micro-finance institution", P2P network lending platform has lower barriers to entry, efficient and fast operation and innovative mode of "financial disintermediation". It has enriched the traditional financial industry, effectively promoted the development of our financial services market. But, as a result of lending to P2P network platform in the initial stage of development, with a large number of platform in the run, the withdrawal difficult, the problem such as collapse, illegal fund-raising, divert client funds, such as a ponzi scheme a serious risk also appeared, this shows fully convincingly that in $\mathrm{P} 2 \mathrm{P}$ lending industry in China the lack of regulation, serious impact on the development of the industry and the financial services market. The issue of risk and regulation of P2P lending platform in China is taken seriously. Based on the present situation of the P2P lending platform development in our country, its development in the process of credit risk, transaction risk, legal risk and so on are analyzed, and puts forward the corresponding regulatory measures, to strengthen the development of P2P lending platform in China is of great importance.
\end{abstract}

\section{Introduction}

The concept of $\mathrm{P} 2 \mathrm{P}$ comes from foreign countries and the essence of $\mathrm{P} 2 \mathrm{P}$ lending is similar to private lending. Lenders provide funds to borrowers through intermediaries. P2P loans are originally intended to help poor people solve short-term capital problems and have a charitable nature. Not for profit purposes, this model make the majority of rural people get out of poverty. Some profitable financial companies see business opportunities and begin to imitate this model, charging certain interest or management fees, which is the origin of P2P lending model. The benefits of advances in internet technology have made it possible to borrow online. The Internet allows lenders to offer loans to distant borrowers via online lending platforms, greatly expanding their scope of business. P2P network lending platform as a new type of financial service institution that integrates the internet, finance, and intermediation. With its own characteristics of efficient and fast operation, low barriers to entry, and the innovative mode of "financial disintermediation", it has played a great role in the field of microfinance, effectively making up for the shortcomings in the traditional financial field. It meets the financing requirements of the traditional financial marginalized groups, improves the utilization efficiency of social idle funds, and perfects the financial service system of our country.

However, the following series risks of the platform are exposed. According to the data from the industrial research institute, $75 \mathrm{P} 2 \mathrm{P}$ network lending platforms experienced problems such as running the road, cash withdrawals difficulty and closing down in 2013. By 2016,1158 P2P network lending platforms had closed down and found it difficult to withdraw money. The risk problems of $\mathrm{P} 2 \mathrm{P}$ network lending platforms have been exposed, and the supervision of P2P network lending 
industry in China is insufficient, and the problem of its free development is also concerned by people.

\section{Development Status of P2P Network Lending Platforms}

Development Status of P2P Network Lending Platform in China. Since the establishment of the first P2P online lending platform, PPDAI in 2007, the P2P online lending platform has been developing rapidly in China, and many $\mathrm{P} 2 \mathrm{P}$ online lending platforms have been established successively. By March 2017, there were 6695 P2P network lending platforms in China. The number of online lending platforms is increasing day by day, transaction volume has kept blowout, which reached 2.804938 trillion in 2016, China's P2P network lending scale has been "explosive" growth. However, with the explosion of P2P network lending platform, its problems and risks are gradually exposed. According to data from the industrial research institute show that in 2016,1158 P2P network lending platforms had closed down and found it difficult to withdraw money. The risk problems of $\mathrm{P} 2 \mathrm{P}$ network lending platforms have been exposed, and the supervision of $\mathrm{P} 2 \mathrm{P}$ network lending industry in China is insufficient, and the problem of its free development is also concerned by people.

Table 1 P2P network lending platform status quo

\begin{tabular}{llll}
\hline Year & Turnover & Number of platform & Number of problem platforms \\
\hline 2007 & - & 1 & - \\
2008 & - & 1 & - \\
2009 & 1.5 & 7 & - \\
2010 & 6 & 16 & 2 \\
2011 & 84 & 34 & 6 \\
2012 & 229 & 101 & 13 \\
2013 & 893 & 531 & 99 \\
2014 & 3292 & 1291 & 334 \\
2015 & 11805.65 & 2567 & 1254 \\
2016 & 28049.38 & 2448 & 1158 \\
\hline
\end{tabular}

Source: Industrial research institute

The Risk of P2P Network Lending Platform in China. Risks exist in all stages of P2P lending, which together restrict the healthy development of P2P lending industry in the future. The borrower faces the risk of credit and information leakage, the lender faces the risk of anti-fraud and anti-money laundering, the $\mathrm{P} 2 \mathrm{P}$ platform itself faces the risk of fund management, the risk of data disclosure and the risk of liquidity.

Fund Management Risks. Under the existing operating mode, investors lend money to borrowers through bidding, the money goes to the platform account, the funds are opaque, and there is the risk of illegal fund-raising. Nowadays, many P2P platforms set up transit accounts in third-party payment companies to realize risk control. On the one hand, for the convenience of accounting, on the other hand, to ensure the security of user funds, but this method is not $100 \%$ reliable. First, the third party payment itself is in a weak regulatory environment; second, the third 
party only acts as an intermediary, not taking risks, once the capital problems occur, the platform operation will also face problems.

Data Disclosure Risks. The online operation mode connects both the borrowers and lenders completely through the Internet, and investors can hardly know the financial status of the platform, and few platforms actively publish their own financial information. There are a few platforms in advertising claims $1 \%$ of the indicator of bad debt, its authenticity is questionable. In addition to the bad debt rate, there is also the capital circulation process, overdue repayment status and other information that plays an important role in decision-making, which is unknown to investors, thus increasing the capital risk.

Liquidity Risks. According to the current mode of operation, whether online or offline, P2P platforms provide borrowers' credit review, capital settlement, payment collection service, platform system maintenance and other services including offline surveys. Depending on the borrower interest fee and investor account management fee or membership fee to maintain the operation. P2P start-up cost is low, but the operating cost is very high. Moreover, according to the liquidity preference of investors, the platform generally provides the function of cash withdrawal at any time. If the management is not good, it is easy to occur similar bank runs, once liquidity risk appears, it may lead to the bankruptcy of the platform and make investors unable to withdraw their loans.

\section{An Empirical Analysis on the Risk of P2P Network Lending Platform in China}

Credit Index Design . The original data in this paper are taken from the detailed operating data of 99 P2P network lending platforms in 2017, covering more than a dozen provinces and cities such as Shandong, Beijing, Shanghai, Shenzhen, Jiangsu, etc. The data is based on the data published on the website of online lending tianyan and first online lending before May 5, 2017.

Platform operation index (operation) $=$ average borrowing period/time the platform has been online. This variable is used to measure the operating experience of P2P lending platforms. If platform operation index of the platform is lower, the more times the platform completes the collection of loans and the richer the operating experience of the platform is. Rich operation experience shows that the platform has more mature operation mode, risk control and management. Volume (transact). This variable directly reflects the size of a platform's operation scale, and also reflects the platform's brand, credit, technology and other qualities from the side. The larger the transaction amount, the lower risk problems. The number of investors (lender). This variable directly reflects the popularity of the platform. The higher the number of investors is, the wider the resources the platform has, the less the risks occur.Average borrowing rate.This variable reflects that under normal circumstances, the lower the borrowing rate of the platform, the stronger risk control ability, absorbing capital loan ability. Press = cumulative loan balance/number of borrowers. This variable describes the platform's debt status and brand strength. The more debtors there are, the higher the default rate and the greater the risk.

Model Hypothesis. P2P online lending platform carries out risk assessment based on whether or not it defaults, and the default value is 1 and the non-default value is 0 . It uses the latest data of the platform to fit the model, and builds a reduced evaluation model that can be tested, improved and updated:

$$
\operatorname{Ln}\left(\frac{P_{i}}{1-P_{i}}\right) \approx \ln e^{X_{i} \beta}+\mu_{i}=X_{i} \beta+\mu_{i}
$$


Data Regression and Result Analysis. Taking P2P network loan platform as dependent variable, default value 1 and non-default value 0 before May 2017, using five credit indexes as covariable, using Logic regression model to analyze, the final regression results are as follows:

\begin{tabular}{|c|c|c|c|c|}
\hline \multicolumn{5}{|l|}{ Dependent Variable: } \\
\hline \multicolumn{5}{|c|}{ Method: ML - Binary Logit (Quadratic hill climbing) } \\
\hline \multicolumn{5}{|l|}{ Sample: 199} \\
\hline \multicolumn{5}{|c|}{ Included observations: 99} \\
\hline \multicolumn{5}{|c|}{ Convergence achieved after 9 iterations } \\
\hline \multicolumn{5}{|c|}{ Covariance matrix computed using second derivatives } \\
\hline Variable & Coefficient & Std. Error & z-Statistic & Prob. \\
\hline $\bar{c}$ & -6.994698 & 1.769735 & -3.952398 & 0.0001 \\
\hline $\mathrm{L}$ & $-1.64 \mathrm{E}-05$ & $3.48 \mathrm{E}-05$ & -0.470365 & 0.6381 \\
\hline $\mathrm{T}$ & 7.81E-06 & $1.40 \mathrm{E}-05$ & 0.556255 & 0.5780 \\
\hline$P$ & 0.000945 & 0.000267 & 3.533622 & 0.0004 \\
\hline $\mathrm{R}$ & 0.359911 & 0.111533 & 3.226951 & 0.0013 \\
\hline Mean dependent var & 0.262626 & \multicolumn{2}{|c|}{ S.D. dependent var } & $\overline{0.442301}$ \\
\hline S.E. of regression & 0.301545 & \multicolumn{2}{|c|}{ Akaike info criterion } & 0.689253 \\
\hline Sum squared resid & 8.547360 & \multicolumn{2}{|c|}{ Schwarz criterion } & 0.820319 \\
\hline Log likelihood & -29.11801 & \multicolumn{2}{|c|}{ Hannan-Quinn criter. } & 0.742282 \\
\hline Restr. log likelihood & -57.00282 & \multicolumn{2}{|c|}{ Avg. log likelihood } & -0.294121 \\
\hline \multirow[t]{2}{*}{ LR statistic (4 df) } & 55.76962 & \multicolumn{2}{|c|}{ McFadden } & 0.489183 \\
\hline & \multicolumn{3}{|c|}{ R-squared } & \\
\hline Probability(LR stat) & $2.24 \mathrm{E}-11$ & & & \\
\hline Obs with $\mathrm{Dep}=0$ & 73 & Total obs & & 999 \\
\hline Obs with $\mathrm{Dep}=1$ & 26 & & & \\
\hline
\end{tabular}

The final regression model is:

$$
\operatorname{Ln}\left(\frac{P}{1-P}\right)=-6.99-1.64 e^{-5} L+7.81 e^{-6} T+0.0009 P+0.36 R
$$

The above model is explained in the economic sense: the smaller the number of investors, the weaker the ability to attract capital, and the lower the popularity of P2P online lending platforms; The larger the loan volume, the larger the operating scale of the platform, the smaller the risk; The more the amount to be repaid, the greater the pressure of recourse; The higher the average borrowing rate is, the greater the pressure on the borrower to repay the loan, the weaker the platform's risk control ability, and the risk of moral hazard is easy to occur.

When the covariables such as average borrowing interest rate, investment number, transaction volume, average loan interest rate and maturity are known, the regression equation can be brought into the regression equation to obtain the probability of default on the P2P network lending platform. This decides whether to choose this platform to carry on the loan transaction. 


\section{Supervision Suggestions of P2P Network Lending Platforms}

Timely Assessment of Risks and Strengthening Precautions. The platform may commission a third party scoring agency to use unified evaluation criteria for comprehensive scoring. The low score platform will give warning, long-term low score, deterioration of risk situation, third party issuing announcements, and investors making sufficient preparations in advance. Step up precautions in advance.

Strengthen the Audit of Borrowers and Develop High-quality Borrowers. The platform can carefully check the qualification of borrowers according to the basic information of borrowers, credit status, financial status, loan conditions and other information, and make full use of effective data to develop high-quality borrowers.

Precision Project Rating, Customer Segmentation. Investors with different risk preferences can customize their investment strategies according to different ratings and interest rates. Provide targeted financing and financial products to different groups of customers.

Perfecting the Supervision Mode. The platform adheres to the principle of transparency, improves the information disclosure mechanism, emphasizes on the limits of illegal fund-raising and entrusts funds to third parties. Platform internal control, industry self-discipline, government regulation, building a platform multi-level supervision system to avoid risks.

Establish a Complete Credit System. China lacks a sound credit system, and and the cost of borrower default and repeated default is low. For P2P platforms, once the default occurs, most of the losses are basically digested by itself. Regulators should issue relevant policies to realize data resource sharing and reduce the cost of platform credit costs.

Clarify the Legal Status of the Platform and Establish Various Mechanisms. The lower entry barriers of P2P network lending industry have led to the soaring number of platforms and increased risks. Market access mechanism and industry exit mechanism should be established to clarify the legal status of platforms and strengthen platform management. Laws and regulations are not sound, the lawsuit cost is high, period is long, P2P platform seldom adopt the way of legal proceedings after a borrower default, legal collection is still faced with difficulty in the practice.The laws and regulations of the P2P network lending industry should be established and improved to prevent the platform from running and closing, and promote the healthy development of the platform.

\section{References}

[1] L.L.Liu.Discussion on the Risk and Supervision of Network Lending in China [J].Credit Enquiry,2013 (11): 29-32

[2] J.D.An. P2P Network Lending platform Risk Prevention ,2012 (14): 79-81

[3] P.Dan, J.L.Yang and Y.L.Deng. Empirical study on risk Assessment of P2P loan platform in China[J]. Chinese prices,2016(11)

[4] R.Tao. Internet finance based on P2P loan model [J].Research and observation.2014, (03)

[5] J.Y.Qian, F.Yang. P2P network loan development status and prospects [J]. Financial Forum 2012: 46-51.

[6] F.Wang. Risk Supervision and Prevention of P2P Network Loan Platform in China [J]. China's Circulation Economy, 2016 (11): 121-127 